\title{
Rancang Bangun Alat Ukur Kelembaban Udara Berbasis Sensor Serat Optik Evanescent dengan Cladding Gelatin Tulang Sapi Menggunakan Transmisi Ethernet Shield
}

\author{
Tomi Irawan", Harmadi \\ Laboratorium Fisika dan Instrumentasi, Jurusan Fisika FMIPA Universitas \\ Kampus Unand, Limau Manis, Padang, 25631 \\ *Tomiirawantd11@gmail.com
}

\begin{abstract}
ABSTRAK
Telah dirancang bangun alat ukur kelembaban udara berbasis sensor serat optik evanescent dengan menggunakan cladding gelatin tulang sapi. Cladding gelatin tulang sapi dibuat dengan metode hidrolisis $\mathrm{HCl}$ dengan variasi perendaman 2 hari dan 4 hari. Variasi panjang pengupasan cladding serat optik adalah $1 \mathrm{~cm}, 2 \mathrm{~cm}$, dan $3 \mathrm{~cm}$. Pengukuran kelembaban udara dilakukan di dalam humidity chamber. Sistem sensor terdiri dari laser dioda sebagai sumber cahaya, serat optik cladding tulang sapi sebagai pengindra kelembaban, fotodioda sebagai fotodetektor, mikrokontroler sebagai pengolah sinyal dan ethernet shield sebagai transmisi data nilai kelembaban melalui plafon internet thingspeak. Kelembaban diukur berdasarkan tegangan keluaran fotodioda. Semakin tinggi kelembaban udara maka semakin tinggi tegangan keluaran fotodioda. Hasil karakterisasi sensor menunjukkan serat optik dengan panjang pengupasan $1 \mathrm{~cm}$ adalah yang paling optimum dalam mengindra kelembaban. Nilai sensitifitas sensor yang dirancang adalah $0,0299 \mathrm{~V} / \% \mathrm{RH}$ dengan koefisien determinasi $\mathrm{R}^{2}=0,977$. Persentase rata-rata kesalahan alat ukur yang dirancang adalah 2,25\% dibandingkan dengan alat ukur acuan (humidity meter). Kata kunci: kelembaban udara, sensor serat optik, evanescent, ethernet shield.
\end{abstract}

\begin{abstract}
Humidity meter with evanescent optical fiber sensors using cow bone gelatin cladding has been designed. Cladding cow bone is made by $\mathrm{HCl}$ hydrolysis method with variations of immersion of 2 days and 4 days. Stripping length variation of fiber optic cladding were $1 \mathrm{~cm}, 2 \mathrm{~cm}$, and $3 \mathrm{~cm}$. The humidity was measured by measuring the water vapor in the humidity chamber. The measuring instrument was designed using a sensor system which consists of a diode laser as a light source, optical fiber of cow bone cladding as a sensing humidity, photodiode as a photodetector, a microcontroller as a signal processor and measuring instrument to display the humadity through a personal computer with an additional ethernet shield transmission thingspeak internet ceiling. Humidity was measured based on the output voltage of the photodiode. The higher the humidity the higher the photodiode output voltage. The optical fiber characterization results showed that optical fiber with $1 \mathrm{~cm}$ stripping length were the most optimum in sensing humidity. The sensitivity value of the designed sensor was $0.0299 \mathrm{~V} / \% \mathrm{RH}$ with the coefficient of determination $R^{2}=0.977$. The average percentage error of the instrument was $2,25 \%$ compared to the reference instrument (humidity meter).
\end{abstract}

Keywords: humidity, fiber optic, evanescent sensor, ethernet shield.

\section{PENDAHULUAN}

Gelatin adalah salah satu bahan hidrogel dari polimer alami yang dapat mengalami pembengkakan ketika menyerap air. Gelatin dapat diperoleh dari hidrolisi kolagen parsial turunan dari kulit dan tulang hewan (Rosli dan Sorban, 2015). Gelatin banyak dimanfaatkan dalam industri seperti pengental (thickener), pembentuk gel, pengikat air, pengendap, dan pembungkus makanan. Gelatin mempunyai sifat yang khas di antaranya dapat menunjukan perubahan dari bentuk sol ke gel secara bolak-balik seiring dengan perubahan suhu. Gelatin salah satu material yang peka terhadap uap air sehingga gelatin dapat dimanfaatkan dalam sensor kelembaban udara (Setiawati, 2009).

Kelembaban udara merupakan kadar uap air di udara yang dapat mempengaruhi proses fisika, kimia, dan biologi pada bahan. Tingkat kandungan uap air yang lebih dari batas ambang akan menimbulkan gangguan dan kerusakan, maka diperlukan sensor untuk mendeteksi kelembaban udara (Maddu, 2006). Sensor kelembaban udara yang telah ada seperti higrometer atau sensor kelembaban yang dikembangkan dari bahan keramik (semikonduktor), polimer organik, dan polimer keramik (Faharani dkk., 2014). Sensor kelembaban udara tersebut belum memanfaatkan pengiriman data kelembaban yang terukur. Hal tersebut menuntut untuk 
dikembangkan sensor yang lebih handal dari bahan polimer organik cladding tulang sapi dan pengiriman data melalui ethernet shield. Sensor dengan proses yang relatif sederhana membuat sensor serat optik bahan polimer organik memberikan harapan terciptanya suatu sensor kelembaban yang murah.

Penelitian mengenai sensor kelembaban udara menggunakan bahan dasar gelatin telah dilakukan oleh beberapa peneliti sebelumnya. Alwis dkk., (2013) melakukan penelitian sensor kelembaban udara berbasis sensor serat optik. Hasilnya memperlihatkan bahwa film gelatin dapat digunakan pada alat ukur kelembaban udara karena rentang penginderaan yang besar serta waktu respon yang cepat. Khairunnisa dan Harmadi (2017) telah melakukan rancang alat ukur kelembaban udara dengan sensor serat optik evanescent dengan film gelatin. Hasil karakterisasi serat optik menunjukan serat optik dengan pengupasan panjang $1 \mathrm{~cm}$ adalah yang paling optimum dalam mengindra kelembaban. Hasil yang didapatkan dari sensor serat optik evanescent menggunakan film gelatin memiliki nilai sensitivitas sensor $0,0186 \mathrm{~V} / \%$ dan regresi 0,9538 dengan kesalahan rata-rata $1,56 \%$.

Penelitian sebelumnya menunjukan bahwa gelatin sangat berpengaruh terhadap respon dari kelembaban udara. Gelatin yang telah digunakan oleh peneliti sebelumnya menggunakan gelatin komersial yang tidak disebutkan bahan baku pembuatan gelatin. Gelatin yang digunakan dalam penelitian ini adalah gelatin yang berasal dari tulang sapi yang diolah dengan metode hidrolisis $\mathrm{HCl} 4 \mathrm{M}$. $\mathrm{HCl}$ digunakan bertujuan untuk melarutkan tulang sapi. Telah dirancang alat ukur kelembaban udara berbasis mikrokontroler ATMega328 dengan sensor serat optik evanecent menggunakan film gelatin dari tulang sapi. Hasil pengukuran kelembaban udara yang terukur ditampilkan ke PC (personal computer) melalui jaringan LAN dengan tambahan komponen ethernet shield. Pengukuran yang terbaca akan dibandingkan dengan humidity meter (alat ukur kelembaban udara).

\section{METODE}

\subsection{Alat dan Bahan}

Alat dan bahan yang digunakan gelas piala, gelas ukur, pipet tetes, corong, cawan porselin, $\mathrm{pH}$ Universal, penangas, hot plate magnetic stirrer, termometer, oven, timbangan analitik, tulang sapi, aquades, $\mathrm{HCl} 4 \mathrm{M}$, kertas saring, breadboard, papan PCB, kabel jumper, timah, solder, resistor, trafo, potensiometer, kapasitor, gunting dan pencabut timah solder. Peralatan lain yang digunakan adalah humidity meter dengan sebagai alat pengukur kelembaban udara, Arduino Uno, LCD 2x16, laser dioda, fotodioda, PC (personal computer), wadah uji kelembaban $16 \times 24 \mathrm{~cm}$. Alat dan bahan untuk keperluan pengupasan cladding serat optik berupa BF5R (sensor digital serat optik), pisau cutter, pisau pemotong serat optik, dan amplas.

\subsection{Pembuatan gelatin tulang sapi.}

Proses pembuatan gelatin tulang sapi melalui beberapa tahap. Tulang sapi dibersihkan dari daging dan lemak yang masih menempel, tulang yang telah bersih dipanaskan dengan air mendidih selama 6 jam, kemudian ditiriskan dan dikeringkan. Tulang sapi yang telah dipotong masing-masing sebanyak $100 \mathrm{~g}$ direndam dengan $\mathrm{HCl} 4 \mathrm{M}$ selama 2 hari dan 4 hari. Tulang sapi yang telah lunak (osein) dihidrolisis dengan ditambahkan $\mathrm{H}_{2} \mathrm{O}$ dalam gelas piala dengan temperatur hidrolisis $70^{\circ} \mathrm{C}$ sambil diaduk dengan kecepatan $300 \mathrm{rpm}$. Gelatin yang telah disaring kemudian dikeringkan dalam oven pada suhu $70^{\circ} \mathrm{C}$ selama \pm 30 jam sampai membentuk butiran serbuk.

\subsection{Perancanga dan karakterisasi sensor serat optik}

Gelatin dari tulang sapi dimasukkan ke dalam air pada suhu $70^{\circ} \mathrm{C}$ sambil diaduk dengan pengaduk magnetik hingga bubuk gelatin larut merata. Larutan gelatin didinginkan di udara terbuka hingga mencapai suhu $25^{\circ} \mathrm{C}$ dan larutan gelatin membentuk gel. Pelapisan (coating) inti serat optik dilakukan dengan teknik pencelupan (dip-coating) yaitu denagn mencelupkan bagian 
inti tanpa cladding ke dalam gel gelatin kemudian ditarik pelan-pelan dari wadah gel, selanjutnya dibiarkan mengering sehari semalam.

Karakterisasi yang pertama adalah melihat perbedaan tegangan keluaran berdasarkan panjang pengupasan $1 \mathrm{~cm}, 2 \mathrm{~cm}$, dan $3 \mathrm{~cm}$ dari sensor serat optik cladding udara, cladding dari tulang sapi di udara terbuka selanjutnya karakterisasi sensor serat optik yang cladding-nya sudah dilapisi cladding gelatin tulang sapi di dalam humidity chamber yang dialirkan uap air kemudian tegangan keluaran diukur dengan mutimeter digital. Nilai sensitifitas serat optik dilihat dari nilai fungsi transfer serat optik.

\subsection{Karakterisasi fungsi transfer serat optik}

Karakterisasi sensor serat optik berdasarkan nilai fungsi transfer dengan perbandingan kelembaban udara terhadap nilai desimal ADC Arduino Uno. Perubahan intensitas cahaya yang diterima oleh fotodioda mengakibatkan perubahan tegangan keluaran fotodioda. Tegangan keluaran yang terbaca akan dkonveksi ke nilai desimal ADC. Fungsi transfer ini ditulis ke dalam bahasa pemograman untuk memperoleh nilai $\mathrm{RH}$ pada alat ukur yang dirancang. Perangkat lunak yang dirancang dalam sistem ditunjukan pada Gambar 1.

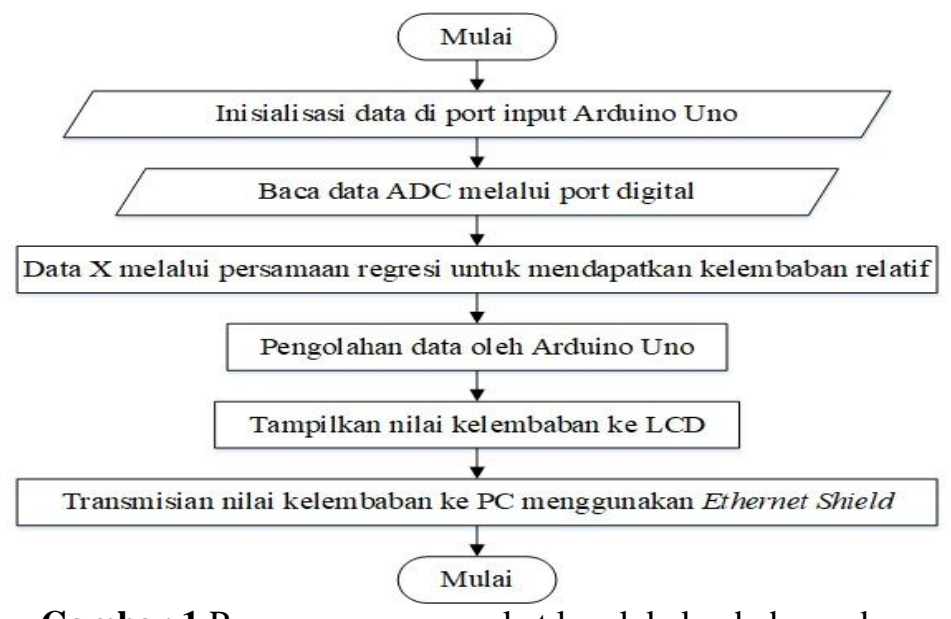

Gambar 1 Perancangan perangkat lunak kelembaban udara

Alat ukur kelembaban udara dirancang dengan serat optik dengan cladding yang peka terhadap kelembaban. Kabel serat optik yang digunakan adalah FD 620-10. Sumber cahaya yang digunakan berasal dari laser dioda. Sumber tegangan yang digunakan untuk fotodioda dan LCD memanfaatkan tegangan keluaran dari Arduino Uno. Cahaya merambat ke dalam serat optik yang telah dilapisi gelatin tulang sapi yang peka terhadap kelembaban, intensitas cahaya yang diterima oleh fotodioda menurunkan tegangan fotodioda sesuai dengan besar intensitas cahaya yang diterima. Tegangan yang terbaca sebagai sinyal analog akan dikonveksi menjadi sinyal digital dikirim ke port $\mathrm{A}_{0}$ pada Arduino Uno dan diubah menjadi sinyal digital oleh ADC Arduino Uno. Perubahan tegangan keluaran pada fotodioda akan diproses oleh Arduino Uno dan nilai kelembaban udara terbaca di LCD dan serial monitor. Hasil yang di baca oleh LCD akan ditransmisikan ke laptop melalui jaringan internet dengan tambahan Ethernet Shield. Secara umum desain prototipe alat ukur kelembaban udara dapat dilihat pada Gambar 2.

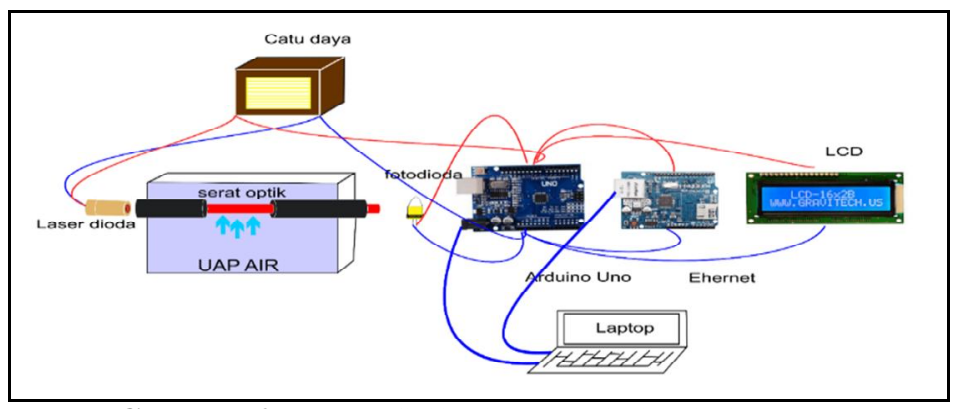

Gambar 2 bentuk fisik alat ukur kelembaban udara 
Hasil pengukuran kelembaban udara yang terbaca pada alat akan dibandingkan dengan alat ukur standar (humidity meter) dan hasil yang sama dapat diamati pada PC (Personal Computer).

\section{HASIL DAN DISKUSI}

\subsection{Hasil Pembuatan Gelatin Tulang Sapi}

Hasil pembuatan gelatin dari tulang sapi menggunakan hidrolisis $\mathrm{HCl} 4 \mathrm{M}$ dengan perendaman 2 hari (sampel 1) dan 4 hari (sampel 2). Gelatin yang didapatkan dari sampel 1 dan sampel 2 ditinjau dari fisik gelatin memiliki perbedaan warna yang signifikan, semakin lama perendaman maka semakin gelap warna gelatin. Menurut Hinterwaldner (1977) menyatakan pada proses pembuatan gelatin perlu dilakukan proses pemucatan yaitu dengan cara penambahan senyawa pereduksi seperti sulfur dioksida. Gelatin tulang sapi membutuhkan waktu rata-rata 48 jam untuk mengubah sampel cair menjadi bubuk. Hasil pembuatan gelatin dapat dilihat pada Gambar 3.
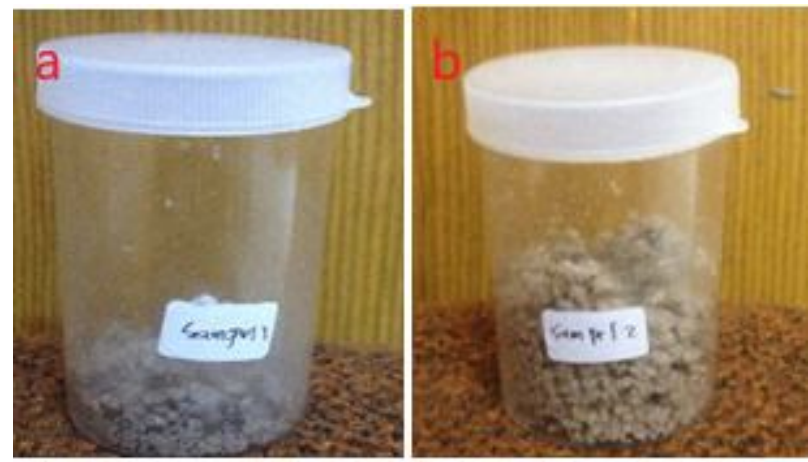

Gambar 3 Hasil pembuatan gelatin tulang sapi \{(a) sampel 1(perendaman tulang sapi 2 hari) \} (b) sampel 2 (perendaman tulang sapi 4 hari)

\subsection{Hasil Karakterisasi Sensor Fotodioda}

Karakterisasi sensor dilakukan untuk mengambarkan kemampuan sensor serat optik dengan membandingkan tegangan keluaran serat optik dengan cladding udara, cladding gelatin, dan cladding kelembaban. Data hasil karakterisasi dapat dilihat pada Gambar 4.

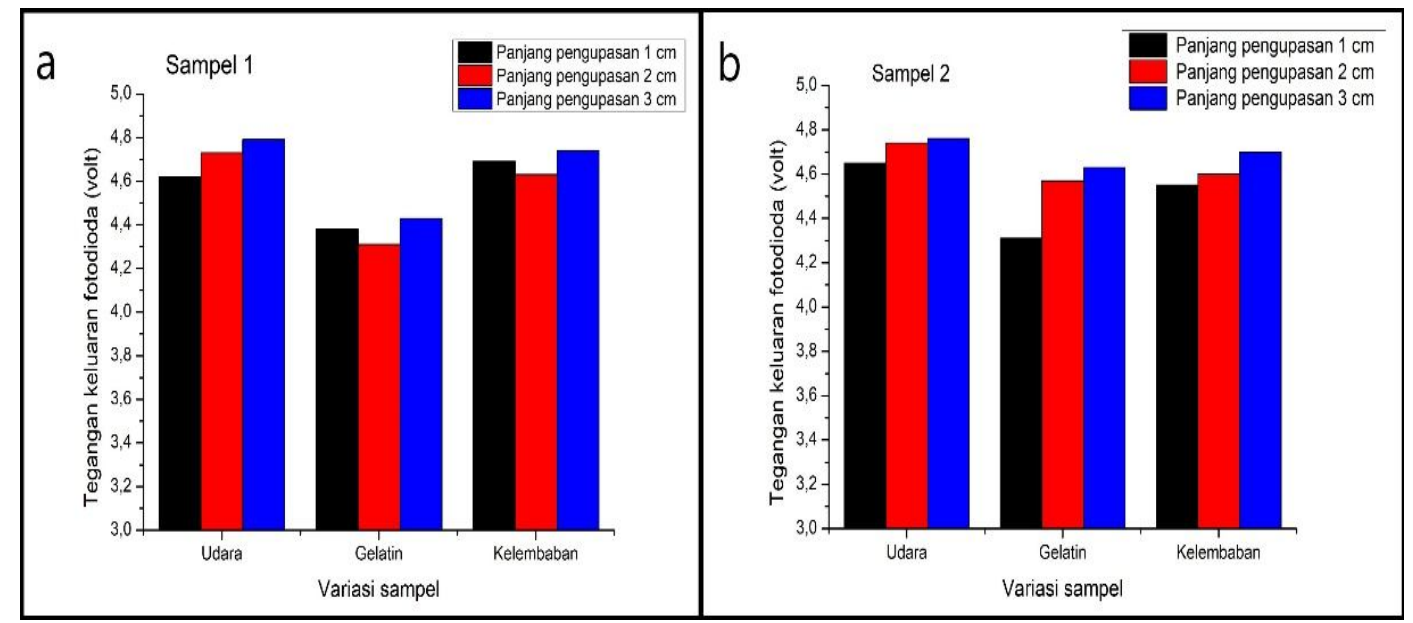

Gambar 4 Grafik hasil karakterisasi tegangan keluaran (a) karakterisasi sampel 1 (b) karakterisasi sampel 2

Karakterisasi sampel 1 dan sampel 2 pengelupasan yang terbaik berdasarkan nilai keluar tegangan semakin kecil setelah penggantian cladding gelatin dan peningkatan tegangan saat diberikan kelembaban. Karakterisasi serat optik juga dipengaruhi oleh panjang pengupasan, semakin panjang pengupasan maka semakin besar tegangan keluaran dari fotodioda. 
Berdasarkan grafik tegangan keluaran yang terbaca oleh fotodioda maka diambil satu pengupasan terbaik.

Karakterisasi sampel 1 didapatkan nilai tegangan keluaran pada panjang pengupasan 2 $\mathrm{cm}$ lebih kecil dibandingkan dengan panjang pengupasan $1 \mathrm{~cm}$ dan $3 \mathrm{~cm}$ ketika dilapisi film gelatin dan tegangan akan meningkat ketika diberikan kelembaban. Berdasarkan pengaruh nilai keluaran pada panjang pengupasan maka diambil panjang $2 \mathrm{~cm}$ yang terbaik. Pada sampel 2 didapatkan nilai keluaran terkecil pada pengelupasan $1 \mathrm{~cm}$, hal yang sama terjadi ketika diberikan cladding gelatin dan kelembaban sedangkan pengupasan $2 \mathrm{~cm}$ dan $3 \mathrm{~cm}$ pada cladding gelatin menghasilkan tegangan yang besar. Tegangan yang besar memperlihatkan terjadinya kebocoran serat optik maka pada sampel 2 pengupasan terbaik pada pengupasan 1 $\mathrm{cm}$. Data hasil karakterisasi menggunakan lux meter untuk mendapatkan sensor paling optimal. Pada sampel 1 panjang pengupasan $2 \mathrm{~cm}$ didapatkan hasil pengukuran intensitas cahaya dilapisi gelatin bernilai 57,7 lux dan setelah diberikan kelembaban di humadity chamber intensitas cahaya yang terbaca sebesar 44,4 lux. Pada sampel 2 panjang pengupasan 1 didapatkan hasil pengukuran intensitas cahaya dilapisi gelatin bernilai 82,1 lux dan pemberian kelembaban di dalam humadity chamber intensitas menjadi 25,1 lux. Berdasarkan dari percobaan pengukuran intensitas cahaya menggunakan lux meter didapatkan sampel 2 panjang pengupasan $1 \mathrm{~cm}$ yang akan dijadikan sebagai sensor kelembaban udara. Hal ini disebabkan oleh semakin pendek pengupasan serat optik maka semakin besar intensitas cahaya yang diteruskan melalui serat optik dan besarnya intensitas cahaya yang diterima oleh lux meter terhadap cladding kelembaban dibandingkan cladding gelatin.

Karakterisasi serat optik juga dapat dilihat melalui kurva linearitas dan histerisis sensor. Data diambil dengan mengamati tegangan keluaran terhadap kelembaban pada suhu ruang humadity chamber $25-30^{\circ} \mathrm{C}$. Kelembaban didapatkan dengan cara mengalirkan uap air ke humadity chamber yang telah dipanaskan terlebih dahulu. Gambar 4 memperlihatkan lineraritas sensor untuk sampel 2 panjang pengupasan 1.

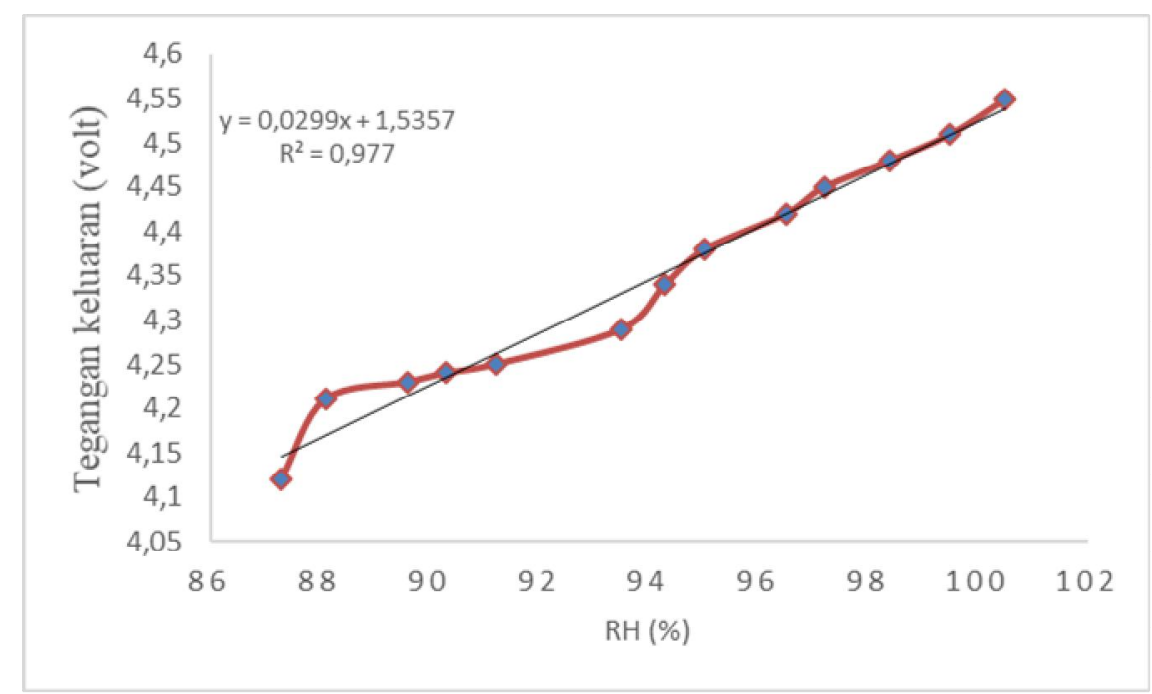

Gambar 5 Grafik hubungan kelembaban udara dengan tegangan keluaran

Gambar 5 menjukan karakterisasi sensor serat optik terhadap kelembaban udara. Hasil tersebut menyatakan semakin tinggi kelembaban udara maka semakin tinggi pula tegangan yang dihasilkan oleh keluaran fotodioda. Intensitas cahaya yang semakin kecil disebabkan oleh gelombang evanescent yang menembus cladding semakin dalam.

\subsection{Hasil Pengamatan Struktur Lapisan Serat Optik}

Struktur lapisan serat optik sebelum dan setelah dilapisi dilihat dengan microscope optik. Serat optik tersebut dilihat strukturnya untuk membandingkan antara yang belum terlapisi dan sudah terlapisi. Struktur tersebut dapat dilihat pada Gambar 5. 

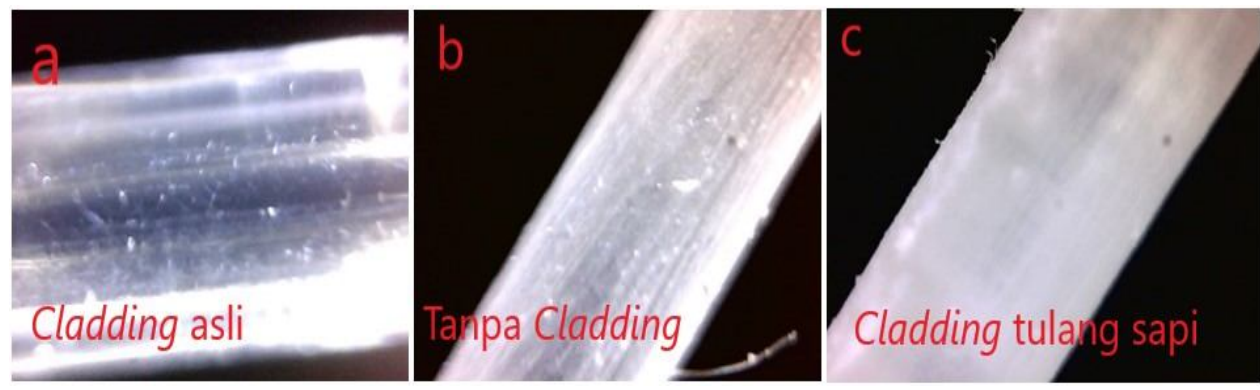

Gambar 6 Struktur lapisan serat optik (a) serat optik cladding asli (b) serat optik tanpa cladding (c) serat optik cladding tulang sapi

Gambar 6 menunjukan serat optik sampel 2 panjang pengupasan $1 \mathrm{~cm}$ dengan cladding belum dikupas, terlihat permukaan serat optik yang halus dan cladding yang melapisi serat optik berwarna bening transparan mengambarkan cladding-nya telah dihilangkan dengan cara mengamplas. Tampak permukaan serat optik tersebut cukup kasar setelah dilakukan pengamplasan. Pengamplasan bertujuan menghilangkan cladding bawaan untuk digantikan cladding gelatin tulang sapi.

\subsection{Hasil Karakterisasi Kelembaban Udara Terhadap ADC}

Karakterisasi hubungan antara kelembaban udara dengan ADC dilakukan untuk mendapatkan fungsi transfer yang digunakan di dalam modul Arduino UNO untuk mendapatkan hasil pengukuran kelembaban udara.

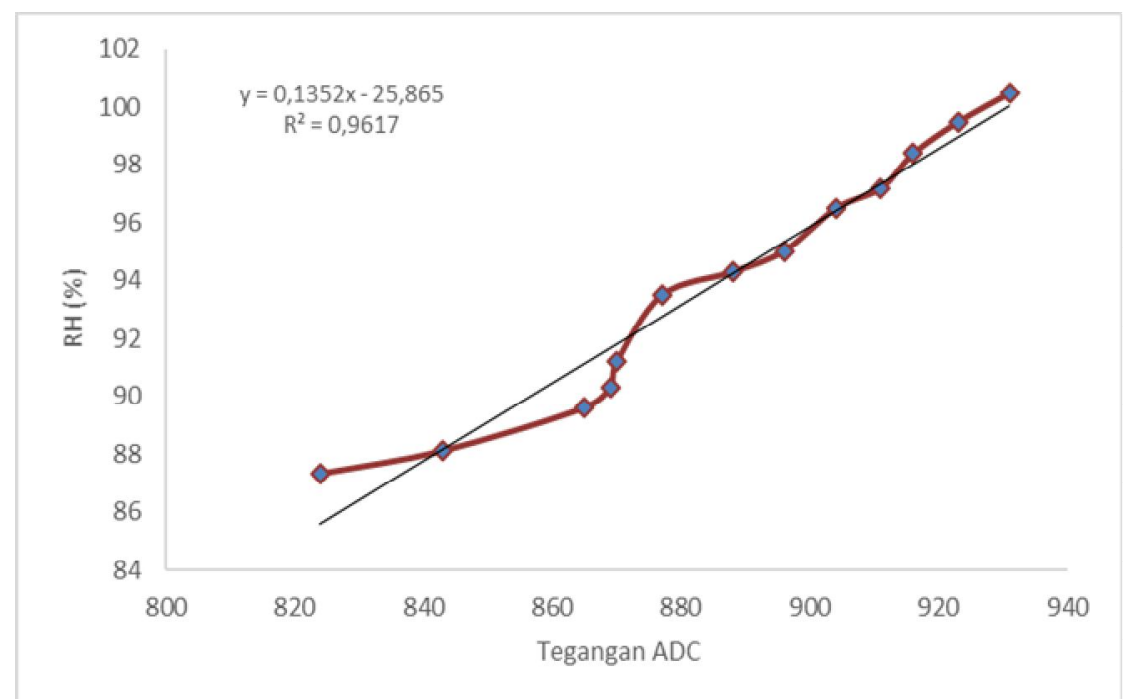

Gambar 7 Grafik hubungan tegangan ADC terhadap kelembaban

Gambar 7 menunjukan hubungan kelembaban udara terhadap tegangan analog to digital converter $(A D C)$ pada sampel 2 panjang pengupasan $1 \mathrm{~cm}$ di peroleh persamaan $\mathrm{y}=$ $0,1352 \mathrm{x}-25,865$, diman nilai $\mathrm{x}$ adalah tegangan masukan ADC dari keluaran fotodioda yang dihubungkan pada kaki $\left(\mathrm{A}_{0}\right)$ Arduino Uno dan y adalah keluaran ADC yang sebagai nilai kelembaban udara terukur yang ditampilkan pada LCD dan PC menggunakan ethernet shield. Nilai 0,1352 merupaka besarnya faktor konveksi ADC, sedangkan nilai -25,865 merupakan tegangan offset dari ADC. Hasil koefisien korelasi $\left(\mathrm{R}^{2}\right)$ yang didapatkan sebesar 0,9617, dan Grafik yang terbentuk mendekati linearitas.

\subsection{Hasil Pengujian Akhir Alat Ukur Kelembaban Udara}

Pengujian akhir alat ukur kelembaban ini merupakan hasil pembacaan sensor serat optik, melihat seberapa akurat tingkat ketelitian dari alat ukur yang dirancang dengan alat ukur standar kelembaban (humadity meter). Hasil pengujian alat ukur dapat dilihat pada Tabel 1. 
Tabel 1 Perbandingan alat ukur serat optik dengan humadity meter

\begin{tabular}{ccc}
\hline $\begin{array}{c}\text { Kelembaban udara } \\
\text { alat ukur yang } \\
\text { dirancang }(\%)\end{array}$ & $\begin{array}{c}\text { Kelembaban udara } \\
\text { alat ukur humadity } \\
\text { meter }\end{array}$ & Error(\%) \\
\hline 87,3 & 84,7 & 2,98 \\
88,1 & 85,4 & 3,06 \\
89,6 & 87,7 & 2,12 \\
90,3 & 88,3 & 2,21 \\
91,2 & 89,0 & 2,41 \\
93,5 & 91,1 & 2,57 \\
94,3 & 92,0 & 2,44 \\
95,02 & 93,6 & 1,49 \\
96,5 & 94,1 & 2,49 \\
97,2 & 95,9 & 1,34 \\
98,4 & 96,1 & 2,34 \\
100 & 97,2 & 2,80 \\
100 & 99 & 1,00 \\
\hline Rata-rata error & & 2,25 \\
\hline
\end{tabular}

Hasil pengukuran antara alat yang dibuat dengan alat standar (humadity mater) didapatkan nilai error sebesar 2,25\%. Beberapa faktor yang menyebabkan besarnya nilai error yang didapatkan disebabkan karena sensor yang dirancang masih sangat rentang terhadap kesalahan sistematis dan pemakain sensor serat optik secara berulang-ulang mengakibatkan kemampuan gelatin untuk menyerap kelembaban berkurang sehingga mengakibatkan kurang stabil dalam penyerapan intensitas cahaya.

\subsection{Data Hasil Kelembaban Udara Pengiriman Ethernet Shield}

Data hasil kelembaban relatif (RH) yang dirancang akan ditransmisikan ke PC melalui ethernet shield. Pengiriman data yang dilakuakna melalui database gratis melalui plafon internet thingspeak dengan tambahan ethernet shield. Data hasil pengukuran yang diolah oleh Arduino Uno akan terkirim ke akun thingspeak yang telah dibuat. Hasil pengukuran dapat dilihat pada Tabel 2 .

Tabel 2 Data kelembaban udara yang ditransmisikan dengan Ethernet shield

\begin{tabular}{ccccc}
\hline \multirow{2}{*}{ Percobaan } & Waktu & \multirow{2}{*}{$\begin{array}{c}\text { Data } \\
\text { yang } \\
\text { masuk }\end{array}$} & $\begin{array}{c}\text { Kelembaban relatif } \\
\text { shield }\end{array}$ & $\begin{array}{c}\text { Alat ukur } \\
\text { standar }\end{array}$ \\
\hline \multirow{3}{*}{1} & $2018-19-09-18: 01: 23$ & 1 & 93,13 & \\
& $2018-19-09-18: 01: 45$ & 2 & 93,14 & \\
& $2018-19-09-18: 02: 09$ & 3 & 93,32 & 94,4 \\
& $2018-19-09-18: 02: 19$ & 4 & 94,15 & \\
& $2018-19-09-18: 02: 32$ & 5 & 94,6 & \\
2 & $2018-19-09-18: 03: 03$ & 1 & 95,12 & \\
& $2018-19-09-18: 03: 14$ & 2 & 95,43 & \\
& $2018-19-09-18: 04: 15$ & 3 & 95,90 & \\
& $2018-19-09-18: 04: 20$ & 4 & 96,02 & \\
3 & $2018-19-09-18: 04: 32$ & 5 & 96,43 & \\
& $2018-19-09-18: 05: 06$ & 1 & 98,12 & \\
& $2018-19-09-18: 05: 17$ & 2 & 98,23 & \\
& $2018-19-09-18: 06: 28$ & 3 & 99,21 & \\
& $2018-19-09-18: 06: 39$ & 4 & 99,15 & \\
& $2018-19-09-18: 06: 45$ & 5 & 100 & \\
& & & &
\end{tabular}

Pengampilan data dilakuakan dalam 3 kali pengulangan yang tampil pada thingspeak. Hasil yang didapatkan menunjukan bahwa ethernet shield dapat berperan dalam pengiriman 
data. Data yang ditransmisikan juga dapat diakses langsung pada akun yang telah dibuat jika alat yang dirancang selalu terhubung dengan router melalui kabel LAN.

\section{KESIMPULAN}

Berdasarkan hasil penelitian yang dilakuakan dapat disimpulkan. Sensor kelembaban udara yang dirancang berhasil dilakukan. Hasil karakterisasi sensor didapatkan sampel 2 (perendaman 4 hari) dengan pengupasan panjang serat optik $1 \mathrm{~cm}$ sebagai sensor kelembaban. Rancangan sensor kelembaban yang didapatkan berbanding lurus antara tegangan keluaran dengan kelembaban udara di dalam humadity chamber, dapat dilihat dari fungsi transfer kelembaban udara terhadap ADC yaitu $\mathrm{y}=0,1352 \mathrm{x}-25,865$. Sensitivitas sensor bergantung pada panjang pengupasan cladding, nilai sensitivitas yang didapatkan sebesar 0,1352 termaksud sensitivitas yang cukup baik. Nilai rara-rata error yang didapatkan dari alat yang dirancang dengan alat ukur humadity meter sebesar 2,25\%.

\section{DAFTAR PUSTAKA}

Alwis, L., Sun, T., Grattan, K. T. V., Optical Fiber Based Sensor Technology For Humidity And Moisture Meansurement; Review Of Recent Progress (Elseiver, Amsterdam, 2013), hal 4052-4074.

Faharani, H., Waginan, R., Hamidan, M. N., Humidity Sensor Principle, Mecharisme., And Febrication Technologies, (A Comprehensive Review Sensor, Basel, 2014) hal 739-781.

Hinterwaldner, R., Technology of gelatin manufactue, in the science and technology of gelatin, A.G ward and A. Courts, (Academic press, London, 1997) hal 56-62.

Khairunnisa, F., dan Harmadi, 2017, Rancang Bangun Alat Ukut Kelembaban Udara Berbasis Mikrokontroler Atmega328 Dengan Sensor Serat Optik Evanescent Menggunakan Film Gelatin, (Jurnal Fisika Unand, padan, 2017), hal 217-224.

Maddu, A., Modjahidin, K., Sardy, S., Zain, H., Pengembangan Probe Sensor kelembaban Serat Optik dengan Cladding Gelatin, (Makara, Jakarta, 2016), hal 45-50.

Rosli, N., dan Sorban, M., Physicochemical and Struktural Properti Of Asian Swamp Eel (Monopterus Albus) Skin Gelatin As Compared To Boving Gelatin, School Of Food And Technology, (Univesitas Malaysia Terengganu, Kuala Terengganu Malaysia, 2015), hal 699-706.

Setiawati, I.H., Karakterisasi mutu fisika kimia gelatin kulit ikan kakap merah (Lutjanus sp) hasil proses perlukuan asam, Skripsi, IPB, 2009. 